\title{
Interpopulation differences in expression of candidate genes for salinity tolerance in winter migrating anadromous brown trout (Salmo trutta L.)
}

\author{
Peter F Larsen*1,3, Einar E Nielsen ${ }^{1}$, Anders Koed ${ }^{1}$, Dennis S Thomsen², \\ Pål A Olsvik ${ }^{4}$ and Volker Loeschcke 3
}

\author{
Address: ${ }^{1}$ Technical University of Denmark, Danish Institute for Fisheries Research, Department of Inland Fisheries, DK-8600 Silkeborg, Denmark, \\ ${ }^{2}$ Svendborg County, Svendborgvej 135, DK-5762 Vester Skerninge, Denmark, ${ }^{3}$ University of Aarhus, Department of Biological Sciences, DK-8000 \\ Aarhus C, Denmark and ${ }^{4}$ National Institute of Nutrition and Seafood Research, PO Box 2029 Nordnes, N-5817 Bergen, Norway \\ Email: Peter F Larsen* - pfl@difres.dk; Einar E Nielsen - een@difres.dk; Anders Koed - ak@difres.dk; \\ Dennis S Thomsen - dennisthomsen99@yahoo.dk; Pål A Olsvik - pal.olsvik@nifes.no; Volker Loeschcke - volker@biology.au.dk \\ * Corresponding author
}

Published: 29 January 2008

BMC Genetics 2008, 9:12 doi:10.1186/147/-2156-9-12
Received: 14 September 2007

Accepted: 29 January 2008

This article is available from: http://www.biomedcentral.com/I47I-2/56/9/12

(C) 2008 Larsen et al; licensee BioMed Central Ltd.

This is an Open Access article distributed under the terms of the Creative Commons Attribution License (http://creativecommons.org/licenses/by/2.0), which permits unrestricted use, distribution, and reproduction in any medium, provided the original work is properly cited.

\begin{abstract}
Background: Winter migration of immature brown trout (Salmo trutta) into freshwater rivers has been hypothesized to result from physiologically stressful combinations of high salinity and low temperature in the sea.

Results: We sampled brown trout from two Danish populations entering different saline conditions and quantified expression of the $h s p 70$ and Na/K-ATPases $\alpha$ lb genes following acclimation to freshwater and full-strength seawater at $2^{\circ} \mathrm{C}$ and $10^{\circ} \mathrm{C}$. An interaction effect of low temperature and high salinity on expression of both hsp 70 and Na/K-ATPase $\alpha \mathrm{l} b$ was found in trout from the river entering high saline conditions, while a temperature independent up-regulation of both genes in full-strength seawater was found for trout entering marine conditions with lower salinities.

Conclusion: Overall our results support the hypothesis that physiologically stressful conditions in the sea drive sea-run brown trout into freshwater rivers in winter. However, our results also demonstrate intra-specific differences in expression of important stress and osmoregulative genes most likely reflecting adaptive differences between trout populations on a regional scale, thus strongly suggesting local adaptations driven by the local marine environment.
\end{abstract}

\section{Background}

Most fish species migrate at some stage during their life and migration takes place on a variety of temporal and spatial scales. Generally migration is related to feeding or reproduction [1-3], however, in some situations the reasons for migration are largely unknown.
Anadromous salmonids are renowned for their migration between freshwater spawning and nursery areas and marine feeding habitats $[4,5]$. The flexibility of such lifehistory related migration varies greatly among species ranging from completely fixed anadromous, e.g. pink salmon (Oncorhynchus gorbuscha) to entirely non-anadromous/resident life histories such as the Mexican golden 
trout (Oncorhynchus chrysogaster) [6]. For other species extreme flexibility can be found with anadromous and resident individuals within the same population, e.g. Atlantic salmon (Salmo salar), brook char (Salvelinus fontinalis), Arctic char (Salvelinus alpinus), brown trout (Salmo trutta), sockeye salmon (Oncorhynchus nerka) and rainbow trout (Oncorhynchus mykiss) (reviewed by [7]). The brown trout is well-known for its highly flexible life-cycle $[8,9]$. The anadromous form of brown trout, known as seatrout, enter the marine environment on feeding migration as juveniles at the age of 1-3 years and they return to freshwater to spawn as mature adults after 0.5-3 years in the sea $[10,11]$. However, a proportion of the sea population re-enters freshwater before reaching maturity without any apparent explanation. This migration is commonly undertaken during winter and therefore it has been hypothesized as a strategy to escape the physiologically very stressful combination of low temperature and high salinity in the sea. Previous studies have indeed shown that physiological suboptimal temperatures and salinities can critically lower osmoregulation ability in sea-run brown trout [12-14].

Since anadromous brown trout populations may experience different local combinations of salinity and temperature during their sea phase the ability of responding to osmoregulatory stress may vary among populations. As a result they may have developed different osmoregulatory abilities/adaptations to local physical and chemical environmental conditions. Such local adaptations are defined as when individuals in their native environment on average have higher fitness than individuals/genotypes originating from a population inhabiting another environment [15]. So far, no studies have assessed to what extent variation in osmoregulatory capacities may be related to adaptation to the local marine environment in anadromous salmonids. However, some studies have suggested that the local marine environment could constitute an important component in relation to local adaptation in brown trout, e.g. Hansen et al. (2002). They showed that the major requirements for local adaptation to evolve in Danish brown trout populations were fulfilled, i.e. sufficient spatial genetic differentiation [16,17], temporal stability of genetic composition and large effective population sizes. Furthermore they demonstrated that adaptation most likely would occur on a regional basis encompassing several populations encountering similar marine selection regimes [16]. Finally, tagging experiments suggest that many populations of sea-run brown trout from different regions experience different environmental challenges in the sea. Some populations have been shown to have very local migration patterns close to the river of origin, while fish from other populations undertake long and different feeding migrations [18].
In this study the two trout populations originate from rivers draining into sea areas with highly different salinity conditions. The first population (River Ribe) enters full strength seawater in the North Sea/Wadden Sea (33 ppt) and the second population (River Grenaa) enters brackish water in the Kattegat (24 ppt) (Figure 1). Hansen et al. (2002) showed genetic structuring on a regional scale among Danish brown trout populations potentially related to sea salinity. Furthermore unpublished data from our lab has demonstrated significant $(\mathrm{P}<0.0001)$ genetic differentiation between trout from river Grenaa and river Ribe with an $\mathrm{F}_{\mathrm{ST}}$ for seven microsatellite loci of 0.045 (95\% confidence intervals bootstrapped across loci $=0.017-0.080)$.

Changes in gene expression has been suggested as an important component for adaptation to different environmental conditions [19-22]. However, so far, no studies are available where variation in gene expression related to osmoregulatory capacities under salinity and temperature stress in natural fish populations have been studied. Thus, Fangue et al. (2006) studied intraspecific variation in expression of a heat shock gene, $h s p 70$, in relation to thermal tolerance in two populations of killifish (Fundulus heteroclitus) distributed along a steep thermal gradient on the East-coast of North America: They showed a tight coupling of thermal tolerance to the heat shock response and a higher expression of $h s p 70$, following heat stress in northern compared to southern killifishes, most likely because southern fishes had adapted to higher annual temperatures [23]. Therefore, studying the pattern and variation in gene expression among natural populations

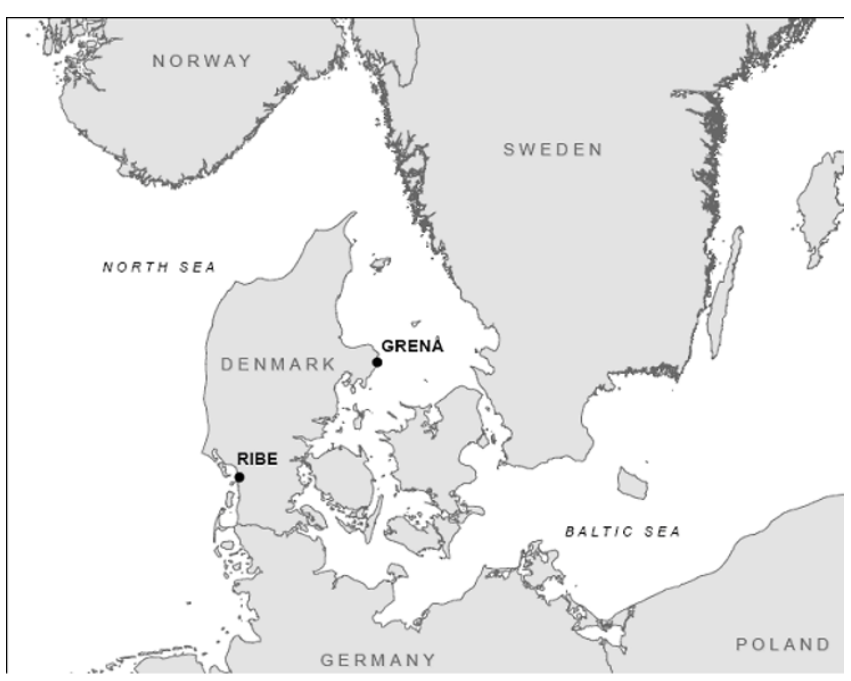

Figure I

Map showing the location of River Ribe and River Grenaa in Denmark, represented by the towns of same name where the rivers enter the sea. 
shows high potential for revealing important functional differences involved in local adaptation to different environmental conditions.

Heat shock proteins (hsps) are good candidate genes for studying physiological stress since they are induced by multiple stressors, including osmotic and temperature stress. They are known to posses cytoprotective functions working as highly effective molecular chaperons refolding or degrading misfolded proteins [24]. Especially $h s p 70$ is a commonly used indicator of physiological stress in multiple organisms, including fishes [25-27]. In relation to osmotic stress previous studies have suggested that hsps are important elements for acclimation of Atlantic salmon (Salmo salar) to hyperosmotic conditions [28] but also to restore osmotic homeostasis following osmotic stress [25]. Another group of interesting candidate genes for osmotic stress are the $\mathrm{Na} / \mathrm{K}$-ATPase genes. $\mathrm{Na} / \mathrm{K}$-ATPases are known to be critical for maintenance of ion balance and homeostasis of teleost fishes [29] and especially migration from seawater to freshwater, and vice versa, requires large changes in levels of $\mathrm{Na} / \mathrm{K}$-ATPase proteins and activity [4]. A number of recent studies have demonstrated a tight correlation between expression of $\mathrm{Na} / \mathrm{K}$ ATPase gene expression and environmental salinity in several salmonids, including brown trout [30-32].

In this study we investigated intra- and interpopulation variation in gene expression of $h s p 70$ and the $N a / K$-ATPase $\alpha 1 b$ subunit in winter migrating anadromous brown trout following acclimation to different combinations of salinity and temperature stress in a "common garden" setup. We wanted to study whether low temperatures at sea in winter could result in a stressful interaction effect explaining migration of sea trout into freshwater rivers. Secondly, we wanted to test the hypothesis of intraspecific variation in gene expression and salinity tolerance related to the local marine conditions experienced by trout from rivers entering different marine conditions. The results are discussed in relation to population structure, local adaptation and conservation of anadromous salmonids, in particular in relation to transplantation and reestablishment of brown trout populations.

\section{Results}

No mortality was observed in trout from River Ribe at any salinity or temperature (Fig. 2). In trout from River Grenaa no mortality was observed in freshwater, but in seawater a mortality of $18 \%$ and $9 \%$ was observed at $10^{\circ} \mathrm{C}$ and $2{ }^{\circ} \mathrm{C}$, respectively (Fig. 2).

Induced levels of $h s p 70$ were found to be significantly higher in trout from River Ribe acclimated in seawater and $2{ }^{\circ} \mathrm{C}$ compared to all other Ribe samples (Fig. 3). Furthermore, an interaction effect of both salinity $(\mathrm{p}<0.05)$ and temperature $(\mathrm{p}<0.01)$ was observed in expression of $h s p 70$ in trout from River Ribe $(\mathrm{p}<0.01)$. In trout from River Grenaa significantly higher levels of $h s p 70$ was
River Ribe

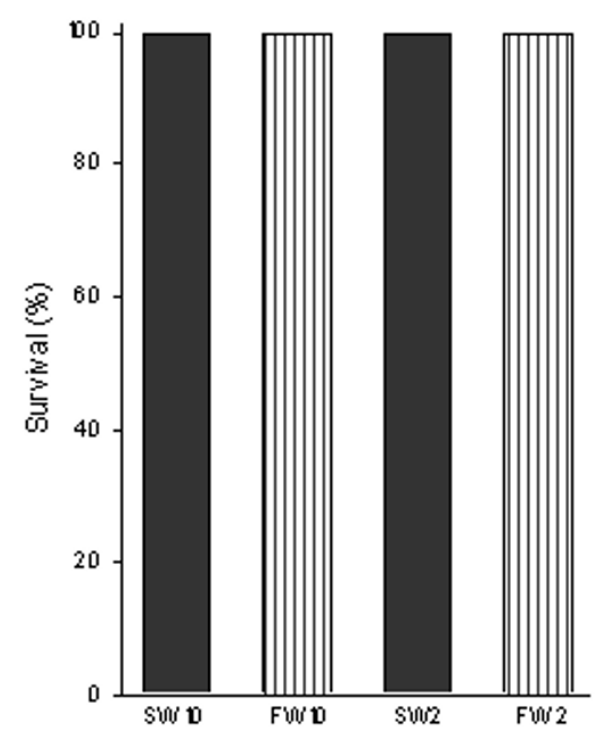

River Grenå

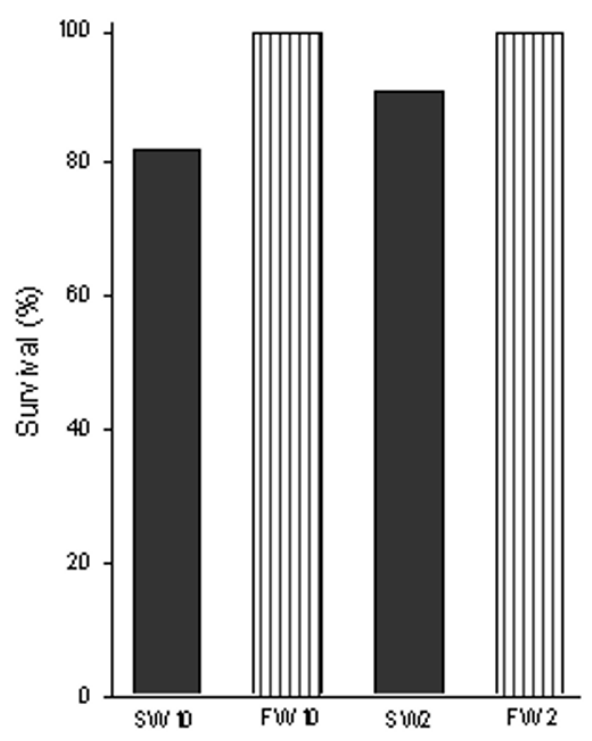

Figure 2

Survival of trout from River Ribe and River Grenaa following acclimation to freshwater (FW) and seawater (SW) at $2^{\circ} \mathrm{C}$ and $10^{\circ} \mathrm{C}$ (number of individuals in experimental groups: $\mathrm{n}=9-\mathrm{II}$ ). 
Hsp70 Ribe

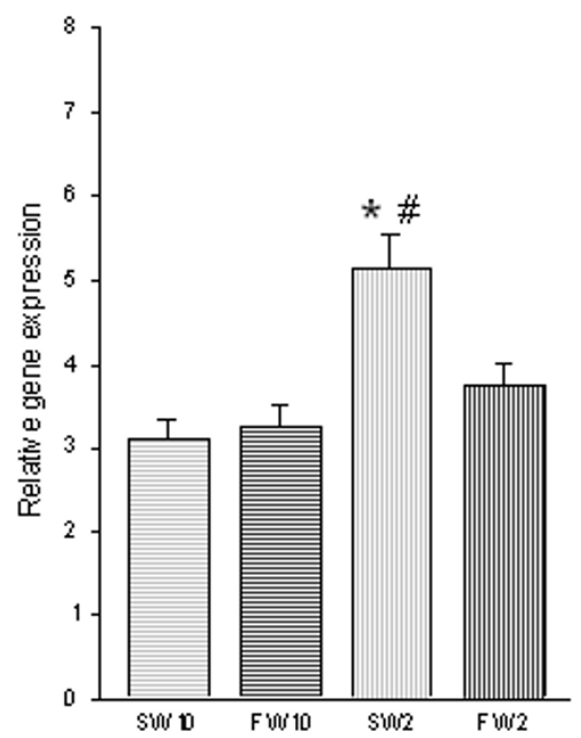

Hsp70 Grenå

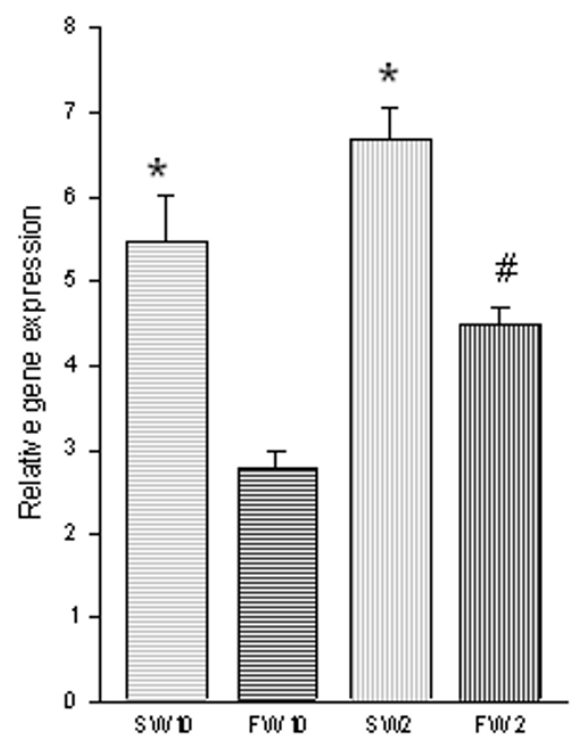

Figure 3

Expression of $h s p 70$ in gill tissue of trout from River Ribe and River Grenaa following acclimation to freshwater (FW) and seawater (SW) at $2^{\circ} \mathrm{C}$ and $10^{\circ} \mathrm{C}$. Amounts of $h s p 70 \mathrm{mRNA}$ are normalized to the corresponding EFI $\alpha$ abundance from the same sample, and mean values are expressed in arbitrary units \pm SE (number of individuals in experimental groups: $\mathrm{n}=8$ ). * indicates significant difference between salinity treatments $(P<0.05)$ and \# indicates significant difference between temperature acclimation groups at the same salinity $(P<0.05)$.

observed in trout from seawater at both $10^{\circ} \mathrm{C}$ and $2{ }^{\circ} \mathrm{C}$ (Fig. 3) compared to freshwater acclimated trout. Moreover we found $h s p 70$ to be significantly higher expressed in trout from freshwater at $2{ }^{\circ} \mathrm{C}$ compared to $10^{\circ} \mathrm{C}$ (Fig. 3). The two-way ANOVA showed a significant effect of both salinity $(\mathrm{p}<0.01)$ and temperature $(\mathrm{p}<0.01)$, but no interaction effect was observed $(p=0.5314)$ in River Grenaa trout. A comparison of intra-specific variation, showed a significant higher expression of $h s p 70$ in trout from River Grenaa in seawater at both $2^{\circ} \mathrm{C}(\mathrm{p}<0.05)$ and $10^{\circ} \mathrm{C}(\mathrm{p}<0.01)$ compared to trout from River Ribe. No significant differences in expression of $h s p 70$ were observed in freshwater.

In general, the $\mathrm{Na} / \mathrm{K}$-ATPase $\alpha 1 b$ gene was observed to be significantly higher expressed in seawater compared to freshwater in trout from both populations, although this difference was not significant in trout from River Ribe at $10^{\circ} \mathrm{C}$ (Fig. 4). The two-way ANOVA identified an interaction effect of temperature $(\mathrm{p}<0.05)$ and salinity $(\mathrm{p}<$ $0.01)$ in trout from River Ribe $(\mathrm{p}<0.05)$. In trout from River Grenaa a highly significant effect of salinity $(\mathrm{p}<$ $0.01)$, but no temperature $(\mathrm{p}=0.7407)$ nor interaction effect was observed $(\mathrm{p}=0.8503)$ in expression of the $\mathrm{Na} /$ $K$-ATPase $\alpha 1 b$ gene. In the intra-specific comparison, trout from River Grenaa showed a significantly higher expression of $\mathrm{Na} / \mathrm{K}$-ATPase $\alpha 1 b$ in seawater at $10^{\circ} \mathrm{C}(\mathrm{p}<$ $0.01)$ compared to trout from River Ribe at the same temperature (Fig. 4), whereas no significant difference was observed at $2^{\circ} \mathrm{C}(\mathrm{p}=0.2738)$. No significant differences in expression of $\mathrm{Na} / \mathrm{K}$-ATPase $\alpha 1 b$ were observed in freshwater.

\section{Discussion}

In this study we identified a strong interaction effect of low seawater temperature and expression of $h s p 70$ and $\mathrm{Na} / \mathrm{K}$-ATPase $\alpha 1 b$ in sea trout from River Ribe, thereby supporting previous suggestions that sea-run brown trout enter freshwater rivers in winter due to osmoregulatory stress in relation to the combination of high salinity and low temperatures. At the same time we observed strong indications of lower salinity tolerance in trout from River Grenaa (seawater mortality); combined with higher expression of $h s p 70$ and $\mathrm{Na} / \mathrm{K}$-ATPase $\alpha 1 b$ in trout from River Grenaa maintained in full strength seawater demonstrating intraspecific variation in gene expression and osmoregulative capacities between the two trout populations. This variation most likely reflects adaptive differences between populations on a regional scale and strongly suggests adaptation to the local marine environment. 
NaK-ATPase $\alpha$ ib trout Ribe

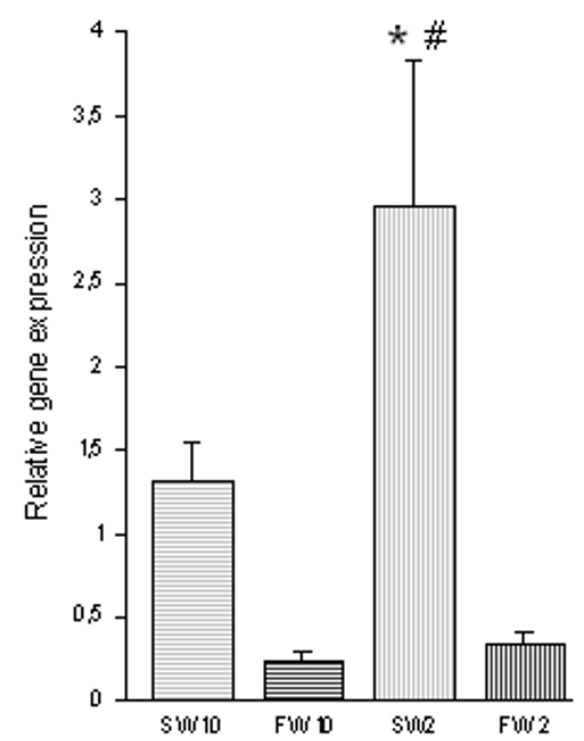

NaK-ATPase $\alpha$ 1b trout Grenå

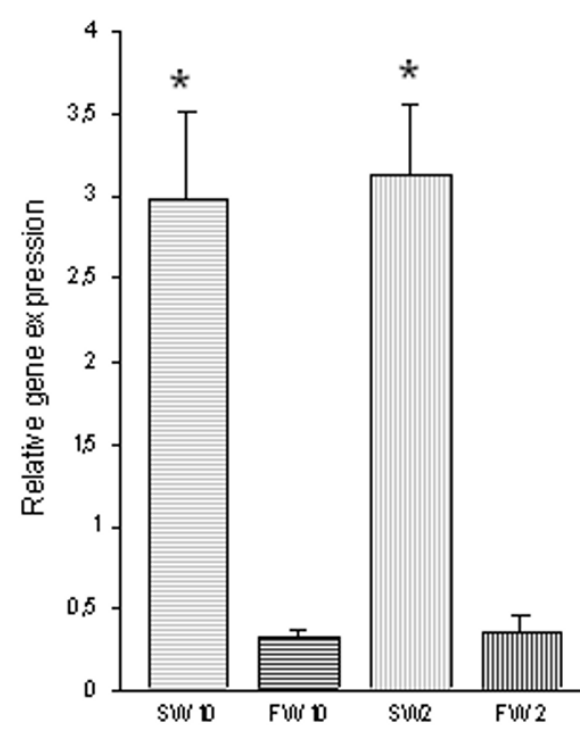

\section{Figure 4}

Expression of Na/K-ATPase $\alpha \mathrm{lb}$ in gill tissue of trout from River Ribe and River Grenaa following acclimation to freshwater $(\mathrm{FW})$ and seawater (SW) at $2^{\circ} \mathrm{C}$ and $10^{\circ} \mathrm{C}$. Amounts of Na/K-ATPase $\alpha$ Ib mRNA are normalized to the corresponding EFI $\alpha$ abundance from the same sample, and mean values are expressed in arbitrary units \pm SE (number of individuals in experimental groups $n=8)$. * indicates significant difference between salinity treatments $(P<0.05)$ and \# indicates significant difference between temperature acclimation groups at the same salinity $(P<0.05)$.

\section{Freshwater migration of sea-run brown trout}

Winter migration of sea-run brown trout into freshwater rivers has been suggested as a strategy to overcome physiological stress resulting from the combination of high salinity and low temperature in the marine environment potentially resulting in lethal conditions for brown trout $[5,14]$. In this study, we demonstrated a significant interaction effect of "cold" seawater and the expression of the general stress gene $h s p 70$ in River Ribe trout, whereas in trout from River Grenaa we observed significant $h s p 70$ induction in both seawater experiments independent of temperature. These observations indicate physiological stress for trout in high saline waters, particularly in winter where the general metabolism is low. Similarly to expression of $h s p 70$ we observed an interaction effect of cold seawater and expression of the $\mathrm{Na} / \mathrm{K}$-ATPase $\alpha 1 b$ gene in trout from River Ribe and a highly significant up-regulation of the $N a / K$-ATPase $\alpha 1 b$ gene in trout from River Grenaa following seawater acclimation. Combined, the results presented here show that the physiological stressful combination of low temperature and seawater salinity could be responsible for "triggering" migration into freshwater in sea-run brown trout in winter. This observation is in concordance with previous suggestions that some salmonid species may not be fully able to compensate for a reduction in seawater temperature by increasing gill $\mathrm{Na} / \mathrm{K}$ -
ATPase expression and instead induction of heat shock proteins may be highly important for cyto-protection under cold hypersaline conditions [28].

\section{Intra-specific variation in gene expression}

Most studies focusing on osmo-regulation in salmonid fishes have aimed at describing the genes involved [33] and direction of gene expression [4] in comparative studies among species. Few studies have investigated the intraspecific variation in gene expression, and so far no studies have demonstrated any significant intraspecific differences that may explain local adaptive differences in relation to osmoregulative capacities $[32,34]$. Therefore, the present study is the first to document intra-specific differences in gene expression in a salmonid fish species.

We have shown a higher seawater tolerance and lower expression of $h s p 70$ and $\mathrm{Na} / \mathrm{K}$-ATPase $\alpha 1 b$ in trout from River Ribe strongly indicating higher fitness of River Ribe trout in full-strength seawater. Following the definition of Kawecki and Ebert (2004) local adaptations can be defined as when individuals have a higher fitness in their local environment compared to individuals from a foreign population in the same environment [15]. According to this definition our results strongly suggest local adaptation in trout from River Ribe because they apparently have 
higher fitness in their native high saline environment than trout from River Grenaa. The difference between the two populations is most likely caused by the difference in the marine habitats experienced by the two trout populations. Trout from River Grenaa naturally enter brackish water in the Kattegat Sea, whereas trout from River Ribe enter fullstrength seawater, thus explaining why trout from River Grenaa are generally more stressed under high saline conditions. Consequently our results suggest that intra-specific variation in gene expression in relation to salinity tolerance might be important for maintaining population structure among Danish brown trout populations entering different marine conditions. These speculations are supported by Hansen et al. (2002) who suggested that trout populations entering different marine environments may be differently adapted on a regional scale based on seawater salinity.

\section{Sampling in nature}

Several factors concerning sampling of fishes in nature for experimental gene expression studies might potentially have affected the results in the present study. Multiple non-genetic environmental factors affecting gene regulation have previously been discussed [35], however studying environmental stress other factors such as pretreatment or "hardening" might also affect results [36]. This could potentially arise from that trout from River Ribe have spent a part of their life in full-strength seawater in the North Sea, and therefore, when they are acclimated to seawater in this experiment they may not respond so drastically to cold seawater compared to trout from River Grenaa, that, most likely, have fed in the more brackish Kattegat Sea. Moreover, studying migrating salmonids it is generally known that they may "lose" their "seawater regulative capacity" following long-term acclimation to freshwater [37]. However, this ability is known to be regained following acclimation to full strength seawater within 10-15 days - estimated for Atlantic salmon [4] and rainbow trout [38]. Therefore in this study we ensured the seawater acclimation to go on for 19 days in order to make sure potential effects of "time in freshwater" are eliminated. In addition, trout were caught as immature trout, at the same size (no significant differences in length) and they were treated in the same way, kept under the same laboratory conditions, and we therefore consider it unlikely that non-genetic factors have had a major impact on gene expression results in this study. Finally, it is important to consider that we only sampled sea trout in freshwater and therefore our explanation on what might "trigger" migration into freshwater only accounts for this group of trout. Especially since it is wellknown that multiple life-history strategies exist in brown trout [12] it is unclear to what extent winter migration into freshwater or extended marine stay is dependent on life-history or triggered by specific environmental condi- tions. Therefore, it is possible that other trout from the same populations, or from other closely located populations, may over-winter in the sea and that such trout may have genetic adaptations and/or physiological advances doing so.

\section{Conservation}

The observation of increased mortality in eastern Danish sea trout acclimated to full-strength seawater might explain previous observations of increased mortality of stocked hatchery trout compared to indigenous trout in Denmark, e.g. Ruzzante et al. (2004). These authors found, despite extensive stocking for several consecutive years, that for brown trout almost none of the returning spawning individuals were of hatchery origin and therefore suggested that stocked anadromous trout had a very high mortality at sea [17]. In a similar study by Hansen $e t$ al. (2000), they showed that stocked trout had a higher survival and reproductive success as resident trout than as anadromous trout [39]. The low survival of stocked trout entering the sea in these two studies may potentially result from that the majority of hatchery reared brown trout stocked in Denmark during the last forty years originate from the Hårkær hatchery. This hatchery was historically founded with wild trout caught in River Kolding in southeastern Denmark [8]. We therefore hypothesize that stocked trout from the hatchery strain entering seawater as anadromous individuals could experience high osmotic stress and seawater mortality, in a similar way as the trout from River Grenaa in this present experiment. This might, to some extent, explain the extremely low survival of stocked anadromous trout previously observed $[16,17]$. However, the Hårkjær hatchery has been operating for more than one hundred years, and we can therefore not rule out whether hatchery induced selection e.g. to strictly freshwater or potential human induced selection regimes may have resulted in a lower fitness of hatchery trout in the wild. However, we do consider it likely that adaptive differences in salinity tolerance and gene expression among trout populations may play an important role for fitness of anadromous trout, both in natural populations and in artificial breed hatchery strains used for stocking activities.

\section{Conclusion}

Our results support the hypothesis that physiologically stressful conditions in the sea drive sea-run brown trout into freshwater rivers in cold winters. Furthermore, our results also demonstrate intra-specific differences in expression of important stress and osmoregulative genes most likely reflecting adaptive differences between trout populations on a regional scale. The observation that intra-specific variation in salinity tolerance and gene expression might explain previous non-successful stocking activities support the ongoing conservation strategy 
for trout in Denmark. At present the target is to increase natural reproduction of indigenous fish in their native rivers, thereby maintaining local adaptations. If very poor or completely missing recruitment is the case supportive breeding using fry from wild caught spawners is allowed. In the case that the indigenous population has been extirpated reintroduction is conducted using fish from a healthy nearby population experiencing similar environmental conditions both in freshwater and in the sea. Potentially, due to the large differences in salinity tolerance and expression of osmoregulative genes between the two trout populations studied here, several major problems could arise as a result of interbreeding/hybridization between indigenous and stocked trout - e.g. degradation of local adaptations through breakdown of co-adapted gene complexes [40].

\section{Methods}

\section{Sampling and experimental setup}

Immature sea trout were caught by electrofishing in the lower parts of the River Grenaa $(n=39)$ and the River Ribe $(\mathrm{n}=43)$ in January and February 2005. Trout of similar sizes, mean fork length from River Grenaa $(33.2 \mathrm{~cm})$ and River Ribe $(35.7 \mathrm{~cm})$, were transported to the Danish Institute for Fisheries Research, Department of Inland Fisheries, PIT-tagged and acclimated to $10^{\circ} \mathrm{C}$ in re-circulated freshwater. Trout from each of the two rivers were split into two groups maintained at $10^{\circ} \mathrm{C}$ in freshwater and $10^{\circ} \mathrm{C}$ in seawater, respectively. Within these groups (freshwater and seawater) trout were again divided into two groups where the water temperature was lowered from $10^{\circ} \mathrm{C}$ to $2^{\circ} \mathrm{C}$ over a period of four days. Sampling of gill tissue for this experiment was conducted 10 days after lowering the temperature from $10^{\circ} \mathrm{C}$ to $2^{\circ} \mathrm{C}$, which was 19 days from the onset of the acclimation to seawater.

The gill is known as the main organ for osmo-regulation in fishes $[14,41]$ and therefore we focused on this specific tissue. Dissected gill tissue was immediately placed in RNAlater following the manufacturer's instructions (Qiagen, Hilden, Germany). RNAlater preserved samples were stored overnight at $4{ }^{\circ} \mathrm{C}$ and then stored at $-20^{\circ} \mathrm{C}$ until RNA extraction. All trout were maintained at a $10 \mathrm{~h}$ light/ $14 \mathrm{~h}$ dark cycle and no food was supplied during the experiment. Thus, since all fish were sampled on the same day they were also fasted for the same period of time.

\section{RNA extraction}

Total RNA was extracted using both the Trizol method (Invitrogen, Carlsbad, CA, USA) and the RNeasy minikit (Qiagen, Hilden, Germany). Extractions were performed as recommended by the manufacturers except for an additional DNAse treatment step for $15 \mathrm{~min}$ at $25^{\circ} \mathrm{C}$ in order to remove any remaining genomic DNA in the RNeasy extracted samples (Qiagen, Hilden, Germany). Total RNA was stored at $-20^{\circ} \mathrm{C}$. Concentration of extracted RNA was determined at $260 \mathrm{~nm}$ in a standard Hellma cuvette (path length $10 \mathrm{~mm}$ ) using the GeneQuant II (RNA/DNA Calculator, Pharmacia Biotech). Total RNA quality was routinely analyzed using $2 \%$ agarose gel electrophoresis.

\section{Reverse transcription of RNA and real-time quantitative PCR (qRT-PCR)}

Reverse transcription of total RNA into cDNA was performed using the SuperScriptII RNase H-Reverse Transcriptase kit (Invitrogen, Carlsbad, CA, USA) in a reaction volume of $20 \mu \mathrm{l}$ containing $1 \times$ reaction buffer, $5 \mathrm{mM}$ $\mathrm{MgCl}_{2}, 1 \mathrm{mM} \mathrm{dNTP}$ mixture, $0.3 \mu \mathrm{l}$ of anchored oligo$(\mathrm{dT})_{20}$ primer $(2.5 \mu \mathrm{g} / \mu \mathrm{l}), 0.9 \mu \mathrm{l}$ of SuperScriptII reverse transcriptase, and $1 \mu \mathrm{g}$ of total RNA. Following, samples were diluted ten fold and stored at $-20^{\circ} \mathrm{C}$ until qRT-PCR analysis.

For the Real-time quantitative PCR (qRT-PCR) analysis previously published primer pairs were used for $\mathrm{Na} / \mathrm{K}$ ATPase $\alpha 1 b$-subunit [38] and $h s p 70$ [42]. Results were normalized to expression of elongation factor $1 \alpha$ [EMBL: $\underline{\mathrm{AF} 321836}$ ], using the following primers: EF-1 $\alpha$ forward: 5'-GAG AAC CAT TGA GAA GTT CGA GAA G-3'; EF- $1 \alpha$ reverse 5'-GCA CCC AGG CAT ACT TGA AAG-3'. This house keeping gene has been used and found suitable and stable for gene expression normalization (e.g. [21-23]).

PCR products from all primer pairs were checked on a $2 \%$ agarose gel to verify primer specificity and PCR product length and to ensure that they only produced a single amplicon when trout cDNA served as template. Furthermore dilution series were performed to verify amplification efficiency of primer pairs [43].

qRT-PCR was performed on the Ligthcycler 1.2 (Roche Diagnostics, Mannheim, Germany) using SYBR Green chemistry (LightCycler FastStart DNA Master SYBR Green I kit, Roche) and the Lightcycler relative quantification software 3.5 (Roche Diagnostics, Mannheim, Germany). Using this software we employed the fully automated method for $\mathrm{C}_{\mathrm{T}}$-determination called the ${ }^{\text {nd }}$ Derivative Maximum" calculation. The $\mathrm{C}_{\mathrm{T}}$-value is the cycle where the $2^{\text {nd }}$ derivative is at its maximum and ideally this should always be in the heart of the log-linear portion of the reaction. Moreover this method is more objective and reproducible than human mediated crossing point settings (Lightcycler relative quantification software manual). All qRT-PCR reactions were performed as follows: $10 \mathrm{~min}$ at $95^{\circ} \mathrm{C}$, followed by 40 cycles of $95^{\circ} \mathrm{C}$ for $15 \mathrm{~s}, 60^{\circ} \mathrm{C}$ for 10 $\mathrm{s}$ and $72^{\circ} \mathrm{C}$ for $10 \mathrm{~s}$. Melting curve analysis was performed following each reaction to confirm the presence of only a single product in the reaction. Negative control reactions were performed for all samples using RNA that had not been reverse transcribed to control for the possible pres- 
ence of genomic DNA contamination. Genomic DNA contamination was present in all samples, but never constituted more than 1:5000 of starting cDNA copy numbers (data not shown). Therefore genomic DNA contamination reflects only a minor fraction of the final PCR-product and only an insignificant source of error for the data analysis.

\section{Statistical Analysis}

Relative gene expression values were calculated, using the "Comparative method", according to [44]. Data are presented as mean expression levels \pm SE. Gene expression levels were compared using one-way ANOVA, and multiple pairwise comparisons were conducted using Tukeys test between salinities (within populations) or between populations (maintained at the same salinity). Finally, two-way ANOVA was conducted to test for an interaction effect of salinity and temperature within the two trout populations. Significance level was set at $\alpha=0.05$ in all analyses and analyses were conducted using the PAST statistics software [45].

\section{Authors' contributions}

PFL, EEN, AK and DST designed the experiment and PFL carried out the molecular and statistical analyses, DST did the sampling of trout. PAO supplied primers for the hsp70 assay and together with VL provided valuable technical input to the data interpretation. All authors read and approved the final manuscript.

\section{Acknowledgements}

This project was supported by the Danish Rod and Net Fish License Funds and by grants to Peter Foged Larsen from the SLIP research school under the Danish Network for Fisheries and Aquaculture Research financed by the Danish Ministry for Food, Agriculture and Fisheries and the Danish Agricultural and Veterinary Research Council and the Danish Institute for Fisheries Research. The authors thank Henrik Baktoft for graphical assistance, Michael Møller Hansen and Lasse Fast Jensen for invaluable discussions on trout genetics.

\section{References}

I. Harden Jones FR: Fish migration London, Edward Arnold; 1968.

2. Odling-Smee L, Braithwaite VA: The role of learning in fish orientation. Fish and Fisheries 2003, 4:235-246.

3. Hrabik TR, Jensen OP, Martell SJD, Walters CJ, Kitchell JF: Diel vertical migration in the Lake Superior pelagic community. I. Changes in vertical migration of coregonids in response to varying predation risk. Canadian Journal of Fisheries and Aquatic Sciences 2006, 63:2286-2295.

4. Bystriansky JS, Richards JG, Schulte PM, Ballantyne JS: Reciprocal expression of gill $\mathrm{Na}+/ \mathrm{K}+-\mathrm{ATPase}$ alpha-subunit isoforms alpha $I a$ and alpha $I b$ during seawater acclimation of three salmonid fishes that vary in their salinity tolerance. J Exp Biol 2006, 209: 1848-1858.

5. Knutsen JA, Knutsen $\mathrm{H}$, Olsen EM, Jonsson B: Marine feeding of anadromous Salmo trutta during winter. Journal of Fish Biology 2004, 64:89-99.

6. Quinn TP, Myers KW: Anadromy and the marine migrations of Pacific salmon and trout: Rounsefell revisited. Reviews in Fish Biology and Fisheries 2004, I 4:42 I-442.
7. McDowall: Anadromy and homing: two life-history traits with adaptive synergies in salmonid fishes? Fish and Fisheries 200I, 2:78-85.

8. Hansen MM: Estimating the long-term effects of stocking domesticated trout into wild brown trout (Salmo trutta) populations: an approach using microsatellite DNA analysis of historical and contemporary samples. Molecular Ecology 2002, II:1003-1015.

9. Charles K, Guyomard R, Hoyheim B, Ombredane D, Bagliniere JL: Lack of genetic differentiation between anadromous and resident sympatric brown trout (Salmo trutta) in a Normandy population. Aquatic Living Resources 2005, 18:65-69.

10. Elliott JM: Quantitative Ecology and the Brown Trout Oxford, Oxford University Press; 1994.

II. Frier JO: Conservation of brown trout populations in Denmark (in Danish: Bevaring af ørredbestande i Danmark). Nordic Minister Council; 1993.

12. Klemetsen A, Amundsen PA, Dempson JB, Jonsson B, Jonsson N, O'Connell MF, Mortensen E: Atlantic salmon Salmo salar L., brown trout Salmo trutta L. and Arctic charr Salvelinus alpinus (L.): a review of aspects of their life histories. Ecology of Freshwater Fish 2003, I 2: I-59.

13. Hyvarinen $\mathrm{P}$, Heinimaa $\mathrm{S}$, Rita $\mathrm{H}$ : Effects of abrupt cold shock on stress responses and recovery in brown trout exhausted by swimming. Journal of Fish Biology 2004, 64: 1015-1026.

14. Rikardsen AH, Amundsen PA, Knudsen R, Sandring S: Seasonal marine feeding and body condition of sea trout (Salmo trutta) at its northern distribution. Ices Journal of Marine Science 2006, 63:466-475.

15. Kawecki TJ, Ebert D: Conceptual issues in local adaptation. Ecology Letters 2004, 7: | 225-I24I.

16. Hansen MM, Ruzzante DE, Nielsen EE, Bekkevold D, Mensberg KLD: Long-term effective population sizes, temporal stability of genetic composition and potential for local adaptation in anadromous brown trout (Salmo trutta) populations. Molecular Ecology 2002, I I:2523-2535.

17. Ruzzante DE, Hansen MM, Meldrup D, Ebert KM: Stocking impact and migration pattern in an anadromous brown trout (Salmo trutta) complex: where have all the stocked spawning sea trout gone? Molecular Ecology 2004, I3: |433- 1445.

18. Pedersen S, Christiansen R, Glüsing $\mathrm{H}$ : Comparison of Survival, Migration and Growth in Wild, Offspring from Wild (FI) and Domesticated Sea-Run Trout (Salmo trutta L.). In Sea trout: Biology, Conservation, and Management Edited by: Harris G and Milner N. Oxford, Blackwell Publishing; 2007:377-388.

19. Schulte PM: Environmental adaptations as windows on molecular evolution. Comp Biochem Physiol B Biochem Mol Biol 200I, | 28:597-6II.

20. Whitehead A, Crawford DL: Variation within and among species in gene expression: raw material for evolution. Molecular Ecology 2006, I5:II 197-I2II.

21. Scott GR, Rogers JT, Richards JG, Wood CA, Schulte PM: Intraspecific divergence of ionoregulatory physiology in the euryhaline teleost Fundulus heteroclitus: possible mechanisms of freshwater adaptation. J Exp Biol 2004, 207:3399-3410.

22. Scott GR, Schulte PM: Intraspecific variation in gene expression after seawater transfer in gills of the euryhaline killifish Fundulus heteroclitus. Comp Biochem Physiol A Mol Integr Physiol 2005, |41: |76-182.

23. Fangue NA, Hofmeister M, Schulte PM: Intraspecific variation in thermal tolerance and heat shock protein gene expression in common killifish, Fundulus heteroclitus. J Exp Biol 2006, 209:2859-2872.

24. Sorensen JG, Kristensen TN, Loeschcke V: The evolutionary and ecological role of heat shock proteins. Ecology Letters 2003, 6:1025-1037.

25. Smith TR, Tremblay GC, Bradley TM: Hsp70 and a $\mathbf{5 4}$ kDa protein (Osp54) are induced in salmon (Salmo salar) in response to hyperosmotic stress. Journal of Experimental Zoology 1999, 284:286-298.

26. Basu N, Nakano T, Grau EG, Iwama GK: The effects of cortisol on heat shock protein 70 levels in two fish species. General and Comparative Endocrinology 200I, I 24:97-I05.

27. Lejeusne C, Perez T, Sarrazin V, Chevaldonne P: Baseline expression of heat-shock proteins (HSPs) of a "thermotolerant" Mediterranean marine species largely influenced by natural 
temperature fluctuations. Canadian Journal of Fisheries and Aquatic Sciences 2006, 63:2028-2037.

28. Pan F, Zarate JM, Tremblay GC, Bradley TM: Cloning and characterization of salmon hsp90 cDNA: Upregulation by thermal and hyperosmotic stress. Journal of Experimental Zoology 2000, 287:199-2I2.

29. Evans DH, Piermarini PM, Choe KP: The multifunctional fish gill: Dominant site of gas exchange, osmoregulation, acid-base regulation, and excretion of nitrogenous waste. Physiological Reviews 2005, 85:97-I77.

30. Madsen SS, Jensen MK, Nohr J, Kristiansen K: Expression of Na+$\mathrm{K}+-\mathrm{ATPase}$ in the brown trout, Salmo trutta: In vivo modulation by hormones and seawater. American Journal of PhysiologyRegulatory Integrative and Comparative Physiology 1995, 38:RI339-RI345.

3I. Seidelin M, Madsen SS, Blenstrup H, Tipsmark CK: Time-course changes in the expression of $\mathrm{Na}+, \mathrm{K}+-\mathrm{ATPase}$ in gills and pyloric caeca of brown trout (Salmo trutta) during acclimation to seawater. Physiol Biochem Zool 2000, 73:446-453.

32. Mackie P, Wright PA, Glebe BD, Ballantyne JS: Osmoregulation and gene expression of $\mathrm{Na}+/ \mathrm{K}+$ ATPase in families of Atlantic salmon (Salmo salar) smolts. Canadian Journal of Fisheries and Aquatic Sciences 2005, 62:2661-2672.

33. Gharbi K, Ferguson MM, Danzmann RG: Characterization of $\mathbf{N a}$, K-ATPase genes in Atlantic salmon (Salmo salar) and comparative genomic organization with rainbow trout (Oncorhynchus mykiss). Mol Genet Genomics 2005, 273:474-483.

34. Singer TD, Clements KM, Semple JW, Schulte PM, Bystriansky JS, Finstad B, Fleming IA, McKinley RS: Seawater tolerance and gene expression in two strains of Atlantic salmon smolts. Canadian Journal of Fisheries and Aquatic Sciences 2002, 59: I25-135.

35. Cossins AR, Crawford DL: Opinion - Fish as models for environmental genomics. Nature Reviews Genetics 2005, 6:324-333.

36. Loeschcke V, Sorensen JG: Acclimation, heat shock and hardening--a response from evolutionary biology. Journal of Thermal Biology 2005, 30:255-257.

37. Tipsmark CK, Madsen SS, Seidelin M, Christensen AS, Cutler CP, Cramb G: Dynamics of $\mathrm{Na}+, \mathrm{K}+, 2 \mathrm{Cl}(-)$ cotransporter and $\mathrm{Na}+\mathrm{K}+-\mathrm{ATPase}$ expression in the branchial epithelium of brown trout (Salmo trutta) and Atlantic salmon (Salmo salar). Journal of Experimental Zoology 2002, 293:106-II8.

38. Richards JG, Semple JW, Bystriansky JS, Schulte PM: Na+/K+. ATPase (alpha-isoform switching in gills of rainbow trout (Oncorhynchus mykiss) during salinity transfer. J Exp Biol 2003, 206:4475-4486.

39. Hansen MM, Ruzzante DE, Nielsen EE, Mensberg KLD: Microsatellite and mitochondrial DNA polymorphism reveals life-history dependent interbreeding between hatchery and wild brown trout (Salmo trutta L.). Molecular Ecology 2000, 9:583-594.

40. McGinnity P, Prodohl P, Ferguson K, Hynes R, O'Maoileidigh N, Baker N, Cotter D, O'Hea B, Cooke D, Rogan G, Taggart J, Cross T: Fitness reduction and potential extinction of wild populations of Atlantic salmon, Salmo salar, as a result of interactions with escaped farm salmon. Proceedings of the Royal Society of London Series B-Biological Sciences 2003, 270:2443-2450.

4I. Sangiao-Alvarellos S, Laiz-Carrion R, Guzman JM, del Rio MPM, Miguez JM, Mancera JM, Soengas JL: Acclimation of S-aurata to various salinities alters energy metabolism of osmoregulatory and nonosmoregulatory organs. Am J Physiol Regul Integr Comp Physiol 2003, 285:R897-R907.

42. Hansen AC, Rosenlund G, Karlsen R, Olsvik PA, Hemre GI: The inclusion of plant protein in cod diets, its effects on macronutrient digestibility, gut and liver histology and heat shock protein transcription. Aquaculture Research 2006, 37:773-784.

43. Stahlberg A, Hakansson J, Xian XJ, Semb H, Kubista M: Properties of the reverse transcription reaction in mRNA quantification. Clinical Chemistry 2004, 50:509-5I5.

44. Livak KJ, Schmittgen TD: Analysis of Relative Gene Expression Data Using Real-Time Quantitative PCR and the 2[Delta][Delta]CT Method. Methods 200I, 25:402-408.

45. Hammer, Harper DAT, Ryan PD: PAST: paleontological statistics software package for education and data analysis. Palaeontologia Electronica 200I, 4:.
Publish with Biomed Central and every scientist can read your work free of charge

"BioMed Central will be the most significant development for disseminating the results of biomedical research in our lifetime. "

Sir Paul Nurse, Cancer Research UK

Your research papers will be:

- available free of charge to the entire biomedical community

- peer reviewed and published immediately upon acceptance

- cited in PubMed and archived on PubMed Central

- yours - you keep the copyright

Submit your manuscript here:

http://www.biomedcentral.com/info/publishing_adv.asp
BioMedcentral 